\title{
Cellulomonas composti sp. nov., a cellulolytic bacterium isolated from cattle farm compost
}

Correspondence
Sung-Taik Lee
e_stlee@kaist.ac.kr

\author{
Myung-Suk Kang, ${ }^{1}$ Wan-Taek Im, ${ }^{1}$ Hae-Min Jung, ${ }^{1}$ Myung Kyum Kim, ${ }^{1,2}$ \\ Michael Goodfellow, ${ }^{3}$ Kwang Kyu Kim, ${ }^{1}$ Hee-Chan Yang, ${ }^{1,4}$ \\ Dong-Shan $\mathrm{An}^{1}$ and Sung-Taik Lee ${ }^{1}$
}
${ }^{1}$ Department of Biological Sciences, Korea Advanced Institute of Science and Technology (KAIST), Guseong-dong 373-1, Yuseong-gu, Daejeon 305-701, Republic of Korea
${ }^{2}$ Department of Oriental Medicinal Materials and Processing, College of Life Science, Kyung Hee University, 1 Seocheon, Kihung Yongin, Kyunggi 449-701, Republic of Korea
${ }^{3}$ School of Biology, King George VI Building, University of Newcastle, Newcastle upon Tyne NE1 7RU, UK
${ }^{4}$ Mount On Science Co. Ltd, Guseong-dong 373-1, Yuseong-gu, Daejeon 305-701, Republic of Korea

A bacterial strain, TR7-06 ${ }^{\top}$, which has cellulase and $\beta$-glucosidase activities, was isolated from compost at a cattle farm near Daejeon, Republic of Korea. It was a Gram-positive, aerobic or facultatively anaerobic, non-motile, rod-shaped bacterium. Phylogenetic analysis based on 16S rRNA gene sequences showed that this strain belongs to the genus Cellulomonas, with highest sequence similarity to Cellulomonas uda DSM $20107^{\top}(98.5 \%)$. Cell wall analysis revealed the presence of type A4 $\beta$, L-Orn-D-Glu peptidoglycan. The cell-wall sugars detected were mannose and glucose. The predominant menaquinone was $\mathrm{MK}-9\left(\mathrm{H}_{4}\right) ; \mathrm{MK}-8\left(\mathrm{H}_{4}\right)$ was detected in smaller quantities. The major fatty acids were anteiso- $C_{15: 0}, C_{16: 0}, C_{14: 0}$ and $C_{18: 0}$. The polar lipids detected were diphosphatidylglycerol, phosphatidylethanolamine and phosphatidylinositol. The results of DNA-DNA hybridization and physiological and biochemical tests clearly demonstrated that TR7-06 ${ }^{\top}$ represents a novel species. The combined genotypic and phenotypic data show that strain TR7-06 ${ }^{\top}\left(=\mathrm{KCTC} 19030^{\top}=\mathrm{NBRC} 100758^{\top}\right)$ merits description as the type strain of a novel Cellulomonas species, Cellulomonas composti sp. nov.

The genus Cellulomonas has a long taxonomic history and comprises species of clinical (Funke et al., 1995) and environmental (Bagnara et al., 1985; Elberson et al., 2000) significance. The genus was proposed by Bergey et al. (1923) for several organisms which were previously classified by Kellerman \& McBeth (1912) as Bacillus species. Applications of chemotaxonomic, molecular systematic and numerical phenetic methods were significant in the establishment of the genus, and these methods form the basis for its differentiation from closely related genera by a combination of morphological and biochemical properties; in particular, Cellulomonas species can be differentiated from members of related genera on the basis of chemotaxonomic and phenotypic properties (Stackebrandt \& Kandler, 1979).

The GenBank/EMBL/DDBJ accession number for the 16S rRNA gene sequence of strain $\mathrm{TR}^{-}-06^{\top}$ is $\mathrm{AB} 166887$.

API ID32 test results for strain TR7-06 ${ }^{\top}$ and related Cellulomonas strains are available with the online version of this paper.
Along with Oerskovia, Cellulomonas currently belongs to the family Cellulomonadaceae (Stackebrandt \& Schumann, 2000) in the suborder Micrococcineae (Prévot, 1961; Stackebrandt et al., 1997). At the time of writing, the genus contains 14 species with validly published names.

Strain TR7-06 ${ }^{\mathrm{T}}$ was isolated along with a large member of other strains during a study of the cultivable aerobic bacterial community in compost from a cattle farm near Daejeon, Republic of Korea. Strain TR7-06 ${ }^{\mathrm{T}}$ was shown to be a member of the genus Cellulomonas based on partial $16 \mathrm{~S}$ RNA gene sequence data and it was subjected to a taxonomic investigation by using chemotaxonomic, physiological and DNA-DNA hybridization analyses. The results provided evidence that TR7 $-06^{\mathrm{T}}$ is a representative of a novel bacterial species.

TR7- $06^{\mathrm{T}}$ was one of the isolates from the compost, which was composed of cow dung and rice straw, that grew on R2A agar (Difco) plates under aerobic conditions. The strain was maintained on R2A agar; stock cultures were preserved as a 
suspension in glycerol $(20 \%, \mathrm{v} / \mathrm{v})$ at $-70{ }^{\circ} \mathrm{C}$. Biomass for chemotaxonomic studies was prepared by cultivating the strain in shake flasks of R2A broth (Difco) at 150 r.p.m. for 3 days at $30^{\circ} \mathrm{C}$. Cultures were checked for purity, harvested by centrifugation and freeze-dried.

Cell morphology and motility were observed under a Nikon light microscope $(1000 \times$ magnification $)$ with cells grown on R2A agar for 3 days at $30^{\circ} \mathrm{C}$. The Gram reaction was conducted according to the non-staining method described by Buck (1982). Growth at different temperatures and $\mathrm{pH}$ was assessed after 5 days incubation on R2A agar. Salt tolerance was tested in R2A broth supplemented with $1-10 \%$ (w/v) $\mathrm{NaCl}$ after 5 days incubation. Growth was estimated by monitoring $\mathrm{OD}_{600}$. Anaerobic growth was observed in serum bottles by adding thioglycolate $\left(1 \mathrm{~g} \mathrm{l}^{-1}\right)$ to R2A broth and replacing the upper air layer with nitrogen gas. Carbon source utilization and some enzyme activities were tested by using the API 20NE, API ID32 and API 50CH test kits (bioMérieux). Catalase activity was determined using $3 \%(\mathrm{v} / \mathrm{v}) \mathrm{H}_{2} \mathrm{O}_{2}$ and oxidase activity was determined using $1 \%(\mathrm{w} / \mathrm{v})$ tetramethyl $p$-phenylenediamine. Tests for the degradation of DNA [flooding DNase agar plates (Scharlau) with $1 \mathrm{M} \mathrm{HCl}$, casein, chitin, starch (Atlas, 1993), lipid (Kouker \& Jaeger, 1987), xylan and cellulose (Ten et al., 2004) were performed and evaluated after 5 days. Results regarding the physiological characteristics of strain TR7- $-06^{\mathrm{T}}$ are summarized in the species description; the data enable the novel strain to be differentiated from other Cellulomonas species, as shown in Table 1.

Extraction of genomic DNA was performed with a commercial genomic DNA extraction kit (Solgent) and PCR-mediated amplification of the 16S rRNA gene and sequencing of the purified PCR products were carried out according to Kim et al. (2005). Full sequences of the 16S rRNA gene were compiled using SEQMAN software (DNASTAR). The 16S rRNA gene sequences of related taxa were obtained from GenBank. Multiple alignments were performed using the program CLUSTAL_X (Thompson et al., 1997). Gaps were edited in the program BioEdit (Hall, 1999). Evolutionary distances were calculated using Kimura's twoparameter model (Kimura, 1983). Phylogenetic trees were constructed by using a neighbour-joining method (Saitou \& Nei, 1987) and maximum-parsimony (Fitch, 1971) using the program MEGA3 (Kumar et al., 2004) with bootstrap values based on 1000 replications (Felsenstein, 1985).

Purified cell-wall preparations were obtained as described by Schleifer \& Kandler (1972). Amino acids and peptides in cell-wall hydrolysates were analysed by two-dimensional TLC on cellulose plates using solvent systems described by Schleifer \& Kandler (1972). Cell-wall sugars were analysed as described by Staneck \& Roberts (1974). Menaquinones were extracted from cells grown in R2A broth (Difco) and analysed as described by Komagata \& Suzuki (1987) using reverse-phase HPLC. Cellular fatty acid profiles were determined for strains grown on TSA (Difco) for 2 days. The cellular fatty acids were saponified, methylated and extracted according to the protocol of the Sherlock Microbial Identification System (MIDI). Fatty acids analysed by GC (Hewlett Packard 6890) were identified by the Microbial Identification software package (Sasser, 1990). Polar lipids were extracted and examined by two-dimensional TLC (Minnikin et al., 1984).

The $\mathrm{G}+\mathrm{C}$ content of the chromosomal DNA was determined as described by Mesbah et al. (1989) using reversephase HPLC. DNA-DNA hybridization was performed fluorometrically by the method of Ezaki et al. (1989) using photobiotin-labelled DNA probes and microdilution wells. Hybridization was performed with five replications for each sample. The highest and lowest values obtained for each sample were excluded and the means of the remaining three values are quoted as DNA-DNA hybridization values.

Phenotypic properties of strain TR7-06 ${ }^{\mathrm{T}}$ were consistent with its classification in the genus Cellulomonas (Stackebrandt \& Kandler, 1979). It was an aerobic or facultatively anaerobic, Gram-positive, rod-shaped and non-motile actinomycete that did not form mycelium. It contained L-Orn-D-Glu as diamino acid in the peptidoglycan (peptidoglycan type A4 $\beta$ ) and mannose and glucose in the cell wall (cell-wall type VIII). The predominant menaquinone was MK-9 $\left(\mathrm{H}_{4}\right)$ and the DNA G $+\mathrm{C}$ content was $73.7 \mathrm{~mol} \%$.

The almost complete 16S rRNA gene sequence (1453 bp) obtained for strain TR7- $06^{\mathrm{T}}$ was compared with sequences of representatives of the suborder Micrococcineae. High $16 \mathrm{~S}$ rRNA gene sequence similarity was found between the tested strain and representatives of the genus Cellulomonas (94.4-98.3\%), which supports its inclusion in the genus Cellulomonas. It is evident from Fig. 1 that strain TR7- $06^{\mathrm{T}}$ is most closely related to Cellulomonas uda DSM $20107^{\mathrm{T}}$, Cellulomonas gelida DSM $20111^{\mathrm{T}}$ and Cellulomonas iranensis ATCC $700643^{\mathrm{T}}$, supported by a moderately high bootstrap value; $16 \mathrm{~S}$ rRNA gene sequence similarities between strain TR7-06 ${ }^{\mathrm{T}}$ and these three type strains were 97.7$98.3 \%$ (C. uda DSM $20107^{\mathrm{T}}$ showed the highest sequence similarity). However, it is evident from DNA-DNA hybridization data that strain TR7-06 ${ }^{\mathrm{T}}$ and C. $u d a$ DSM $20107^{\mathrm{T}}$ should not be classified within the same species as they shared a DNA-DNA hybridization value of $10.7 \%$, well below the $70 \%$ cut-off point recommended for the delineation of genomic species (Wayne et al., 1987). The organism also has a profile of phenotypic properties that distinguish it from representatives of all species of Cellulomonas with validly published names, including $C . u d a$, the most closely related species (Table 1). Moreover, strain TR7-06 ${ }^{\mathrm{T}}$ could be differentiated easily from the three species of the genus Cellulomonas that are phylogenetically most closely related using tests for the utilization of substrates as sole carbon sources (see Supplementary Table S1 available in IJSEM Online). Unlike C. uda DSM $20107^{\mathrm{T}}$ and C. gelida DSM $20111^{\mathrm{T}}$, strain TR7-06 ${ }^{\mathrm{T}}$ could not utilize salicin or acetate. 
Table 1. Phenotypic properties that distinguish strain $T R 7-06^{\top}$ from the type strains of Cellulomonas species

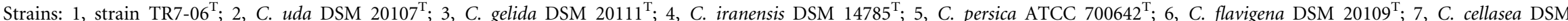

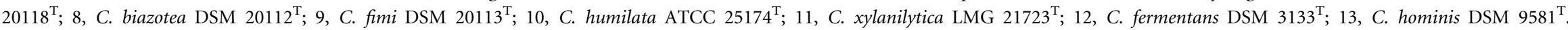

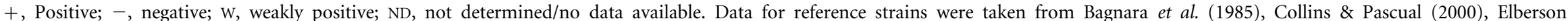
et al. (2000), Funke et al. (1995), Rivas et al. (2004) and Stackebrandt \& Kandler (1979).

\begin{tabular}{|c|c|c|c|c|c|c|c|c|c|c|c|c|c|}
\hline Characteristic & 1 & 2 & 3 & 4 & 5 & 6 & 7 & 8 & 9 & 10 & 11 & 12 & 13 \\
\hline Motility & - & - & + & + & + & - & - & + & + & - & - & - & + \\
\hline Morphology & Rod & Rod & Rod & Rod & Rod & Rod & Rod & Rod & Rod & $\begin{array}{l}\text { Diphtheroid, } \\
\text { coccoid }\end{array}$ & $\begin{array}{l}\text { Rod, } \\
\text { coccoid }\end{array}$ & Polymorphic & Rod \\
\hline Mycelium & - & - & - & - & - & - & - & - & - & + & - & - & - \\
\hline Colony colour ${ }^{\star}$ & $\mathrm{Y}$ & WH & YW & YW & $\mathrm{YW}$ & $\mathrm{Y}$ & $\mathrm{Y}$ & $\mathrm{YW}$ & YW & WH & $\mathrm{Y}$ & WH & $\mathrm{Y}$ \\
\hline Nitrate reduction & + & + & + & + & + & + & + & + & + & - & + & + & + \\
\hline Peptidoglycan & $\begin{array}{l}\text { L-Orn-D- } \\
\text { Glu }\end{array}$ & $\begin{array}{l}\text { L-Orn-D- } \\
\text { Glu }\end{array}$ & $\begin{array}{l}\text { L-Orn-D- } \\
\text { Glu }\end{array}$ & $\begin{array}{l}\text { L-Orn-D- } \\
\text { Glu }\end{array}$ & $\begin{array}{l}\text { L-Orn-D- } \\
\text { Glu }\end{array}$ & $\begin{array}{l}\text { L-Orn-D- } \\
\text { Asp }\end{array}$ & $\begin{array}{l}\text { L-Orn-D- } \\
\text { Glu }\end{array}$ & $\begin{array}{l}\text { L-Orn-D- } \\
\text { Glu }\end{array}$ & $\begin{array}{l}\text { L-Orn-D- } \\
\text { Glu }\end{array}$ & $\begin{array}{l}\text { L-Orn-D- } \\
\text { Glu, Lys }\end{array}$ & $\begin{array}{l}\text { L-Orn-D- } \\
\text { Glu }\end{array}$ & L-Orn & L-Orn \\
\hline Cell-wall sugars $\dagger$ & Glc, Man & $\begin{array}{l}\text { GlcN, } \\
\text { Glc }\end{array}$ & $\begin{array}{l}\text { GlcN, } \\
\text { Glc }\end{array}$ & $\begin{array}{l}\text { GlcN, Rha, } \\
\text { Glc, Man }\end{array}$ & $\begin{array}{l}\text { GlcN, Rha, } \\
\text { Glc, Man }\end{array}$ & $\begin{array}{l}\text { GlcN, Rha, } \\
\text { Rib, Man }\end{array}$ & $\begin{array}{l}\text { Rha, Man, } \\
\text { 6dTal }\end{array}$ & $\begin{array}{l}\text { GlcN, Rha, } \\
\text { 6dTal, Gal }\end{array}$ & $\begin{array}{l}\text { GlcN, Rha, } \\
\text { Fuc }\end{array}$ & $\begin{array}{l}\text { Rha, Glc, } \\
\text { Fuc }\end{array}$ & $\begin{array}{l}\text { Man, Rha, } \\
\text { Fuc }\end{array}$ & $\begin{array}{l}\text { Glc, Rha, } \\
\text { Rib }\end{array}$ & ND \\
\hline \multicolumn{14}{|l|}{ Fermentation of: } \\
\hline D-Glucose & + & + & + & ND & ND & + & + & + & + & + & + & + & + \\
\hline Maltose & + & + & + & ND & ND & + & + & + & + & + & + & + & + \\
\hline L-Rhamnose & - & - & - & ND & ND & - & - & + & + & + & + & - & + \\
\hline Sucrose & + & + & + & ND & ND & + & + & + & + & + & + & + & + \\
\hline D-Xylose & + & + & + & ND & ND & + & + & + & + & + & + & + & + \\
\hline Methyl $\beta$-xyloside & - & - & - & ND & ND & - & - & - & $\mathrm{W}$ & ND & ND & + & + \\
\hline Gluconate & - & - & - & ND & ND & $\mathrm{W}$ & - & - & - & ND & ND & - & + \\
\hline Dextrin & $\mathrm{ND}$ & + & + & + & + & + & - & - & + & + & ND & + & + \\
\hline Mannitol & - & - & - & ND & ND & - & + & - & - & + & ND & + & - \\
\hline \multicolumn{14}{|l|}{ Enzyme activities } \\
\hline Catalase & - & + & + & ND & ND & + & + & + & + & - & + & - & + \\
\hline Cellulase & + & + & + & + & + & + & + & + & + & ND & + & + & - \\
\hline Urease & - & - & - & + & + & - & - & - & - & - & - & - & - \\
\hline \multicolumn{14}{|l|}{ Hydrolysis of: } \\
\hline Aesculin & + & + & + & ND & ND & + & + & + & + & + & + & + & + \\
\hline Gelatin & W & + & + & $\mathrm{W}$ & w & + & - & + & + & $\mathrm{w}$ & W & + & + \\
\hline Major fatty acids $\ddagger$ & $\begin{array}{c}\text { ai- } C_{15: 0} \\
C_{16: 0} \\
C_{14: 0}\end{array}$ & $\begin{array}{c}\text { ai- } C_{15: 0} \\
C_{16: 0} \\
C_{15: 0}\end{array}$ & $\begin{array}{c}\text { ai- } C_{15: 0} \\
C_{16: 0} \\
C_{15: 0}\end{array}$ & ND & ND & $\begin{array}{c}\text { ai- } C_{15: 0} \\
C_{16: 0} \\
C_{14: 0}\end{array}$ & $\begin{array}{c}\text { ai- } C_{15: 0} \\
\mathrm{C}_{16: 0} \\
\text { ai- } \mathrm{C}_{17: 0}\end{array}$ & $\begin{array}{c}\text { ai- } C_{15: 0} \\
\text { i- } C_{15: 0} \\
\quad C_{16: 0}\end{array}$ & $\begin{array}{c}\text { ai- } C_{15: 0} \\
\mathrm{C}_{16: 0} \\
\text { ai- } \mathrm{C}_{17: 0}\end{array}$ & ND & $\begin{array}{c}\text { ai- } C_{15: 0} \\
C_{16: 0} \\
C_{18: 0}\end{array}$ & $\begin{array}{c}\text { ai- } C_{15: 0} \\
C_{16: 0} \\
C_{14: 0}\end{array}$ & $\begin{array}{l}\text { ai- } \mathrm{C}_{15: 0} \\
\mathrm{C}_{16: 0} \\
\text { ai- } \mathrm{C}_{17: 0}\end{array}$ \\
\hline $\begin{array}{l}\text { DNA G +C content } \\
(\mathrm{mol} \%)\end{array}$ & 73.7 & $72.0-76.3$ & $72.4-74.4$ & ND & ND & $72.7-74.8$ & 75 & $71.5-75.6$ & $71.3-72$ & 73 & 73 & 75.8 & $73.0-76.0$ \\
\hline
\end{tabular}

${ }^{*}$ WH, White; Y, yellow; Yw, yellow-white.

or †6dTal, 6-Deoxytalose; Fuc, fucose; Gal, galactose; Glc, glucose; GlcN, glucosamine; Man, mannose; Rha, rhamnose; Rib, ribose.

‡ai, Anteiso; i, iso. 


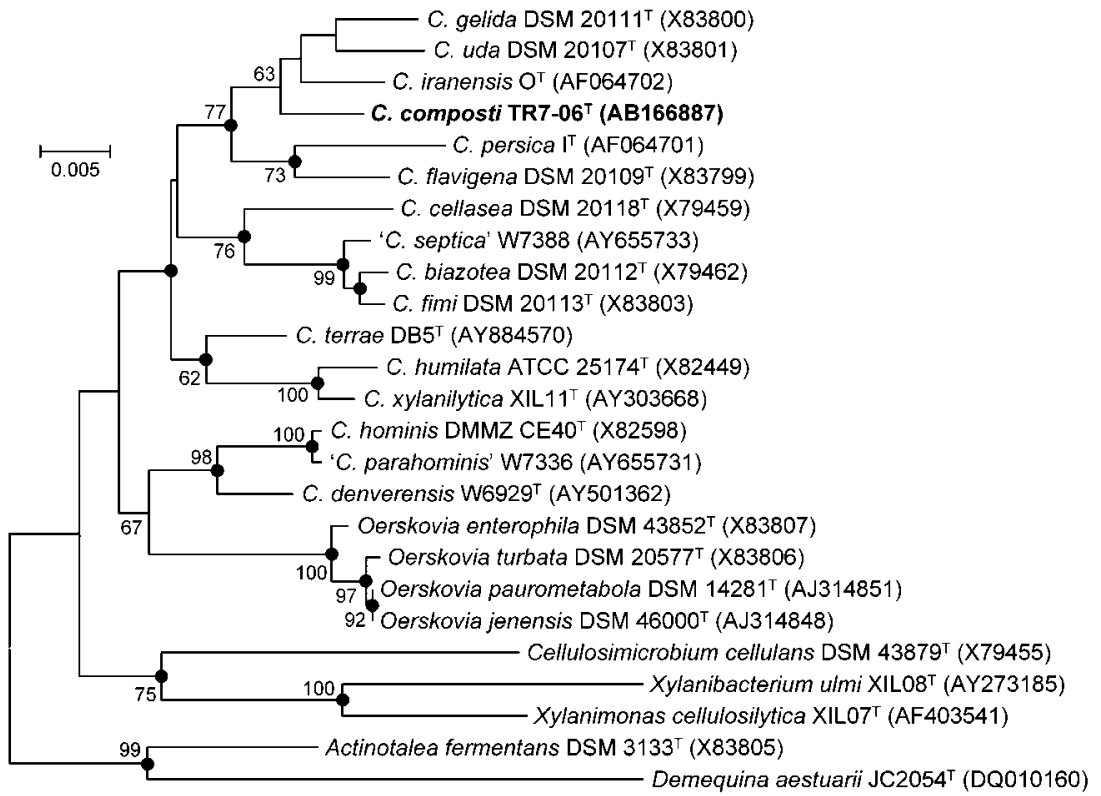

Fig. 1. Phylogenetic tree based on almostcomplete 16S rRNA gene sequences showing relationships between strain TR7-06 ${ }^{\top}$ and representatives of Cellulomonas species (neighbour-joining method). Dots indicate generic branches of the tree that were also found using the maximum-parsimony treeing algorithm. Numbers at nodes indicate levels of bootstrap support (\%) based on a neighbour-joining analysis of 1000 resampled datasets; values greater than $60 \%$ are shown. Bar, 0.005 substitutions per nucleotide site.

The genotypic and phenotypic data indicate that strain TR7- $-06^{\mathrm{T}}$ merits recognition as a representative of a novel species of Cellulomonas. It is proposed that the organism should be classified in the genus Cellulomonas as Cellulomonas composti sp. nov.

\section{Description of Cellulomonas composti sp. nov.}

Cellulomonas composti (N.L. n. compostum compost; N.L. gen. n. composti of compost).

Gram-positive, aerobic or facultatively anaerobic, nonmotile, rod-shaped cells. Colonies on R2A agar plates are circular, smooth, yellow circles within 3 days at $25^{\circ} \mathrm{C}$. Optimal growth occurs at $30^{\circ} \mathrm{C}$ and $\mathrm{pH} 6.8-7.5$. Utilizes D-glucose, maltose and glycogen as sole carbon sources. Acid is produced aerobically and anaerobically from L-arabinose, D-xylose, D-galactose, D-glucose, D-fructose, D-mannose, D-cellobiose, D-maltose, sucrose, D-trehalose, starch, glycogen and gentiobiose. Acid is produced weakly under anaerobic conditions from D-ribose, D-lactose, inulin and D-lyxose. Hydrolyses gelatin weakly. Positive for nitrate reduction. $\beta$-Glucosidase, amylase, cellulase and DNase are produced. Negative for catalase and urease. MK-9 $\left(\mathrm{H}_{4}\right)$ is the predominant menaquinone. The major cellular fatty acids are anteiso- $\mathrm{C}_{15: 0}(44.0 \%), \mathrm{C}_{16: 0}(14.6 \%)$, $\mathrm{C}_{14: 0}(9.0 \%)$ and $\mathrm{C}_{18: 0}(7.9 \%)$. Cell wall sugars are mannose and glucose.

The type strain is TR7- $06^{\mathrm{T}}\left(=\mathrm{KCTC} 19030^{\mathrm{T}}=\mathrm{NBRC}\right.$ $\left.100758^{\mathrm{T}}\right)$, isolated from compost from a cattle farm near Daejeon, Republic of Korea. The G+C content of the genomic DNA of the type strain is $73.7 \mathrm{~mol} \%$ (determined by HPLC).

\section{Acknowledgements}

This work was supported by the Eco-Technopia-21, Ministry of Environment, Republic of Korea.

\section{References}

Atlas, R. M. (1993). Handbook of Microbiological Media. Edited by L. C. Parks. Boca Raton, FL: CRC Press.

Bagnara, C., Toci, R., Gaudin, C. \& Belaich, J. P. (1985). Isolation and characterization of a cellulolytic microorganism, Cellulomonas fermentans sp. nov. Int J Syst Bacteriol 35, 502-507.

Bergey, D. H., Harrison, F. C., Breed, R. S., Hammer, B. W. \& Huntoon, F. M. (editors) (1923). Bergey's Manual of Determinative Bacteriology. Baltimore: Williams \& Wilkins.

Buck, J. D. (1982). Nonstaining (KOH) method for determination of gram reactions of marine bacteria. Appl Environ Microbiol 44, 992-993.

Collins, M. D. \& Pascual, C. (2000). Reclassification of Actinomyces humiferus (Gledhill and Casida) as Cellulomonas humilata nom. corrig., comb. nov. Int J Syst Evol Microbiol 50, 661-663.

Elberson, M. A., Malekzadeh, F., Yazdi, M. T., Kameranpour, N., Noori-Daloii, M. R., Matte, M. H., Shahamat, M., Colwell, R. R. \& Sowers, K. R. (2000). Cellulomonas persica sp. nov. and Cellulomonas iranensis sp. nov., mesophilic cellulose-degrading bacteria isolated from forest soils. Int J Syst Evol Microbiol 50, 993-996.

Ezaki, T., Hashimoto, Y. \& Yabuuchi, E. (1989). Fluorometric deoxyribonucleic acid-deoxyribonucleic acid hybridization in microdilution wells as an alternative to membrane filter hybridization in which radioisotopes are used to determine genetic relatedness among bacterial strains. Int J Syst Bacteriol 39, 224-229.

Felsenstein, J. (1985). Confidence limits on phylogenies: an approach using the bootstrap. Evolution 39, 783-791.

Fitch, W. M. (1971). Toward defining the course of evolution: minimum change for a specific tree topology. Syst Zool 20, 406-416.

Funke, G., Pascual Ramos, C. \& Collins, M. D. (1995). Identification of some clinical strains of CDC coryneform group A-3 and A-4 
bacteria as Cellulomonas species and proposal of Cellulomonas hominis sp. nov. for some group A-3 strains. J Clin Microbiol 33, 2091-2097.

Hall, T. A. (1999). BioEdit: a user-friendly biological sequence alignment editor and analysis program for Windows 95/98/NT. Nucleic Acids Symp Ser 41, 95-98.

Kellerman, F. K. \& McBeth, I. G. (1912). The fermentation of cellulose. Zentralbl Bakteriol Hyg II Abt 34, 485-494.

Kim, M. K., Im, W.-T., Ohta, H., Lee, M. \& Lee, S.-T. (2005). Sphingopyxis granuli sp. nov., a $\beta$-glucosidase-producing bacterium in the family Sphingomonadaceae in $\alpha-4$ subclass of the Proteobacteria. J Microbiol 43, 152-157.

Kimura, M. (1983). The Neutral Theory of Molecular Evolution. Cambridge: Cambridge University Press.

Komagata, K. \& Suzuki, K. (1987). Lipid and cell wall analysis in bacterial systematics. Methods Microbiol 19, 161-207.

Kouker, G. \& Jaeger, K. E. (1987). Specific and sensitive plate assay for bacterial lipases. Appl Environ Microbiol 53, 211-213.

Kumar, S., Tamura, K. \& Nei, M. (2004). MEGA3: integrated software for molecular evolutionary genetics analysis and sequence alignment. Brief Bioinform 5, 150-163.

Mesbah, M., Premachandran, U. \& Whitman, W. B. (1989). Precise measurement of the $\mathrm{G}+\mathrm{C}$ content of deoxyribonucleic acid by high-performance liquid chromatography. Int J Syst Bacteriol 39, 159-167.

Minnikin, D. E., O'Donnell, A. G., Goodfellow, M., Alderson, G., Athalye, M., Schaal, A. \& Parlett, J. H. (1984). An integrated procedure for the extraction of bacterial isoprenoid quinones and polar lipids. J Microbiol Methods 2, 233-241.

Prévot, A. R. (1961). Traité de Systématique Bactérienne. Paris: Dunod (in French).

Rivas, R., Trujillo, M. E., Mateos, P. F., Martínez-Molina, E. \& Velázquez, E. (2004). Cellulomonas xylanilytica sp. nov., a cellulolytic and xylanolytic bacterium isolated from a decayed elm tree. Int J Syst Evol Microbiol 54, 533-536.
Saitou, N. \& Nei, M. (1987). The neighbor-joining method: a new method for reconstructing phylogenetic trees. Mol Biol Evol 4, 406-425.

Sasser, M. (1990). Identification of bacteria by gas chromatography of cellular fatty acids, MIDI Technical Note 101. Newark, DE: MIDI Inc.

Schleifer, K. H. \& Kandler, O. (1972). Peptidoglycan types of bacterial cell walls and their taxonomic implications. Bacteriol Rev 36, 407-477.

Stackebrandt, E. \& Kandler, O. (1979). Taxonomy of the genus Cellulomonas, based on phenotypic characters and deoxyribonucleic acid-deoxyribonucleic acid homology, and proposal of seven neotype strains. Int J Syst Bacteriol 29, 273-282.

Stackebrandt, E. \& Schumann, P. (2000). Description of Bogoriellaceae fam. nov., Dermacoccaceae fam. nov., Rarobacteraceae fam. nov. and Sanguibacteraceae fam. nov. and emendation of some families of the suborder Micrococcineae. Int J Syst Evol Microbiol 50, 1279-1285.

Stackebrandt, E., Rainey, F. A. \& Ward-Rainey, N. L. (1997). Proposal for a new hierarchic classification system, Actinobacteria classis nov. Int J Syst Bacteriol 47, 479-491.

Staneck, J. L. \& Roberts, G. D. (1974). Simplified approach to identification of aerobic actinomycetes by thin-layer chromatography. Appl Microbiol 28, 226-231.

Ten, L. N., Im, W.-T., Kim, M.-K., Kang, M.-S. \& Lee, S.-T. (2004), Development of a plate technique for screening of polysaccharidedegrading microorganisms by using a mixture of insoluble chromogenic substrates. J Microbiol Methods 56, 375-382.

Thompson, J. D., Gibson, T. J., Plewniak, F., Jeanmougin, F. \& Higgins, D. G. (1997). The CLUSTAL_X windows interface: flexible strategies for multiple sequence alignment aided by quality analysis tools. Nucleic Acids Res 25, 4876-4882.

Wayne, L. G., Brenner, D. J., Colwell, R. R., Grimont, P. A. D., Kandler, O., Krichevsky, M. I., Moore, L. H., Moore, W. E. C., Murray, R. G. E. \& other authors (1987). International Committee on Systematic Bacteriology. Report of the ad hoc committee on reconciliation of approaches to bacterial systematics. Int $J$ Syst Bacteriol 37, 463-464. 